\title{
Dietary value and sensory quality of calf meat depending on different n-3 PUFA sources in the diet
}

\author{
M. Zymon and J. Strzetelski ${ }^{1}$ \\ ${ }^{1}$ National Research Institute of Animal Production \\ 32-083 Balice, Poland
}

(Received 3 September 2007; revised version 8 November 2007; accepted 21 November 2007)

\begin{abstract}
The aim of the study was to determine the effect of different n-3 PUFA sources in a calf diet on the health value and sensory quality of veal. A total of 30 bulls were assigned to 3 groups and fed a milk replacer (7-56 days) and concentrates (7-90 days) containing mainly ground cereals, and additionally $10 \%$ linseed cv. Omega or $4 \%$ fish oil. In the control group, the mixture contained no additional fat. At 90 days of age, the bulls were slaughtered and meat samples from the M. thoracis were taken for chemical and fatty acid analysis. Physicochemical and organoleptic analysis of meat was also performed. Linseed reduced the proportion of SFA and increased the level of $\mathrm{C}_{18: 3} \mathrm{n}-3$ in meat fat $(\mathrm{P} \leq 0.05)$. Fish oil reduced the $\mathrm{C}_{18: 0}$ content and increased the proportion of EPA, DPA and DHA $(\mathrm{P} \leq 0.05)$. Both fat supplements increased the n-3 PUFA content $(\mathrm{P} \leq 0.05)$ and reduced the n-6/n-3 acid ratio. The meat of linseed-fed calves was characterized by a lighter colour $(\mathrm{P} \leq 0.05)$ than in the other groups. In fish oil-fed calves, meat flavour, aroma and structure clearly deteriorated in relation to those found in the control group $(\mathrm{P} \leq 0.05)$. When linseed was fed, a tendency $(\mathrm{P}>0.05)$ towards improved juiciness and poorer structure, aroma and flavour of meat in relation to the control group was found. Linseed had no negative effect on the sensory quality of meat. However, fish oil had a clearly adverse effect on meat taste.
\end{abstract}

KEY WORDS: calves, fish oil, linseed, meat quality

\section{INTRODUCTION}

Higher intakes of long-chain n-3 PUFA in the diet have been reported to improve the functions of the immune, nervous and cardiovascular systems in humans (Shahidi and Miraliakbari, 2004). Human nutritionists recommend increasing the daily dose of essential long-chain n-3 PUFA from 0.15 to $0.65 \mathrm{~g} /$ day (Kris-

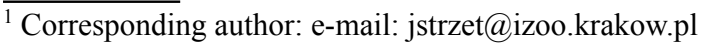


Etherton et al., 2000). Veal and beef are characterized by a low fat content but have a dietetically unfavourable composition of fatty acids. Because PUFA given to animals in feed are largely biohydrogenated microbiologically in the rumen, ruminant meat has a high SFA content that favours the development of many diseases of modern civilization (Bauman et al., 2003). It has been shown, however, that feeding animals with feeds rich in PUFA, especially n-3 PUFA, can have a favourable effect on the health-promoting value of meat by reducing the proportion of SFA and the n-6/n-3 PUFA ratio in meat fat (Raes et al., 2003). Sources of n-3 PUFA in ruminant feeding include some cultivars of linseed rich in linolenic acid (Borowiec et al., 2001), as well as fish oil (Givens et al., 2000), which is rich in eicosapentaenoic (EPA) and docosahexaenoic acids (DHA). In addition to functional meat properties that have a beneficial effect on human health, consumers pay considerable attention to the sensory quality of meat, especially culinary traits such as colour, tenderness and palatability. These traits depend on many factors, including the breed and age of animals, genetic factors, and feeding method (Geay et al., 2001). The aim of the study was to determine the effect of different sources of n-3 PUFA in calf diets on the health value and sensory quality of meat.

\section{MATERIAL AND METHODS}

\section{Animals and feeding}

A total of thirty 7-day-old Polish Holstein-Friesian bull calves were randomly assigned to 3 equal groups. From 7 to 90 days of age the animals were individually fed ad libitum concentrate without (control) or with linseed var. Omega or fish oil (Table 1). During the first feeding period (from 7 to 56 days of age) the calves also received milk replacer containing $20 \%$ of soyabean protein and $40 \%$ of whey. The liquid feed contained $167 \mathrm{~g}$ of powder in $1 \mathrm{~kg}$ of water

Table 1. The components of concentrates, $\%$

\begin{tabular}{lccc}
\hline \multirow{2}{*}{ Feeds } & \multicolumn{3}{c}{ Groups } \\
\cline { 2 - 4 } & control & linseed & fish oil \\
\hline Ground barley & 40.5 & 55.5 & 40.5 \\
Ground wheat & 30.5 & 13 & 27 \\
Wheat bran & 13 & 6 & 10 \\
Soyabean meal & 13 & 12.5 & 15.5 \\
Linseed var. Omega, ground & & 10 & 4 \\
Fish oil & 3 & & 3 \\
Minerals & & 3 & 4 \\
\hline
\end{tabular}

${ }^{1}$ complet CJ, in $1 \mathrm{~kg}$; g: $\mathrm{Ca} 212.8, \mathrm{P} 60, \mathrm{Na} 88, \mathrm{Mg} 25, \mathrm{Zn} \mathrm{4,} \mathrm{Mn} \mathrm{2.5,} \mathrm{Fe} \mathrm{1.5,} \mathrm{vit.} \mathrm{E} \mathrm{0.8;} \mathrm{IU:} \mathrm{vit.} \mathrm{A}$ 450000 , vit. $\mathrm{D}_{3} 100000$ 
solution (3.3\% protein and 3.3\% fat). The feeding plan, feed evaluation and composition of feed mixture were based on IZ-INRA (2001) standards. The calves were kept in individual cages with a wooden floor and cribs for feeds, and had free access to water. The intake of liquid feed and concentrates was monitored daily by weighing feed refusals. At 90 days of age, bulls were slaughtered and meat samples from the $M$. thoracis (MT) were taken for analysis.

\section{Chemical analysis and calculation}

The basic chemical compositions of feeds and meat were determined using the procedures of AOAC (1998); fatty acid composition was estimated in extracted fat using gas chromatography (Pye Unicam 104, $30 \mathrm{~m}$ column). Physicochemical and organoleptic analysis of meat was also performed. $\mathrm{pH}$ was measured 45 min and 24 $\mathrm{h}$ after slaughter. Meat colour was determined with the CIE L*a*b* system (Boccard et al., 1981) using a Minolta CR-310 chroma meter. After 48 -h storage at $4^{\circ} \mathrm{C}$ the instrumental tenderness and thermal weight loss of meat were measured. Meat samples were sliced into $1.5 \mathrm{~cm}$ thick steaks and cooked to an internal temperature of $70^{\circ} \mathrm{C}$ (AMSA, 1995) in an electric cooker at $165^{\circ} \mathrm{C}$. The difference between the precooked and cooked steak weights was divided by the precooked weight to calculate cooking loss percentage. Sensory evaluation of meat (i.e. aroma, palatability, juiciness and tenderness) was performed according to a 5-point scale.

The fat content of concentrates with linseed and fish oil was approx. 3.5-fold higher than that of the control diet (Table 2). Linseed and fish oil had a vary-

Table 2. Nutrient and fatty acid composition of feeds and concentrates

\begin{tabular}{lccccc}
\hline \multirow{2}{*}{ Item } & \multirow{2}{*}{ Linseed } & \multirow{2}{*}{ Fish oil } & \multicolumn{3}{c}{ Concentrates } \\
\cline { 4 - 6 } & & & control & linseed & fish oil \\
\hline Dry matter, \% & 92.5 & 98.7 & 86.2 & 87.0 & 86.6 \\
Crude protein, \% DM & 26.7 & - & 18.5 & 18.3 & 18.1 \\
Fat, \% DM & 40.9 & 98.9 & 1.56 & 5.56 & 5.40 \\
Fatty acids, \% of total fat & & & & & \\
$\mathrm{C}_{18: 0}$ & 4.25 & 2.36 & 2.37 & 3.35 & 2.43 \\
$\mathrm{C}_{18: 1}$ & 23.5 & 24.6 & 22.8 & 22.0 & 22.9 \\
$\mathrm{C}_{18: 2} \mathrm{n}-6$ & 15.8 & 3.87 & 50.2 & 26.3 & 20.6 \\
$\mathrm{C}_{18: 3} \mathrm{n}-3$ & 48.0 & 0.45 & 5.08 & 35.3 & 4.30 \\
$\mathrm{C}_{20: 5} \mathrm{n}-3$ EPA & - & 7.16 & - & - & 6.39 \\
$\mathrm{C}_{22: 6}$ n-3 DHA & - & 11.0 & - & - & 5.91 \\
PUFA n-3 & 48.0 & 22.4 & 5.08 & 35.3 & 17.4 \\
PDIN $^{1}, \mathrm{~g}$ & 143 & - & 112 & 105 & 104 \\
PDIE $^{1}, \mathrm{~g}$ & 44 & - & 113 & 100 & 96 \\
UFL $^{1}$ & 1.04 & 2.82 & 1.1 & 1.1 & 1.1 \\
\hline
\end{tabular}

'IZ-INRA (2001) 
ing effect on the proportion of particular fatty acids in the fat of the diets. In the control diet, $\mathrm{C}_{18: 2} \mathrm{n}-6$ acid accounted for over half of all fatty acids determined. The linseed diet was characterized by a several-fold higher proportion of $\mathrm{C}_{18: 3} \mathrm{n}-3$ compared with the other groups. The fish oil diet was found to have a high EPA and DHA content. Compared with the control diet, the n-3 PUFA content was 7 -fold that of the linseed diet and 3-fold that of the fish oil diet.

\section{Statistical analysis}

The results were analysed statistically using one-way analysis of variance with the GLM model procedures of SAS (2002) (REGW post-test). The differences were assumed to be non-significant at $\mathrm{P}>0.05$.

\section{RESULTS}

There were no significant differences $(\mathrm{P}>0.05)$ in feed and nutrient intake between calves from the particular groups. In relation to the control group, linseed significantly $(\mathrm{P} \leq 0.05)$ improved daily weight gains (by approx. 19\%) and final body weight (by approx. 11\%) (Table 3), but no statistically significant differences were found between calves receiving the control and fish oil diets.

Table 3. Fattening parameters of calves

\begin{tabular}{|c|c|c|c|c|c|}
\hline Item & Control & Linseed & Fish oil & SEM & $\mathrm{P}$ \\
\hline Initial body weight, $\mathrm{kg}$ & 43.2 & 44.1 & 44.5 & 1.10 & 0.25 \\
\hline Final body weight, kg & $97.0^{\mathrm{b}}$ & $108.0^{\mathrm{a}}$ & $98.6^{\mathrm{b}}$ & 1.95 & 0.04 \\
\hline Daily weight gain from 7 to 90 days, $g \cdot$ day $^{-1}$ & $659^{\mathrm{b}}$ & $782^{\mathrm{a}}$ & $623^{\mathrm{b}}$ & 23.3 & $<0.01$ \\
\hline \multicolumn{6}{|l|}{ Daily intake of } \\
\hline milk replacer (powder), $\mathrm{kg}$ & 0.91 & 1.03 & 0.94 & 0.17 & 0.19 \\
\hline concentrate, $\mathrm{kg}$ & 1.03 & 1.07 & 1.01 & 0.04 & 0.83 \\
\hline dry matter, $\mathrm{kg}$ & 1.41 & 1.52 & 1.42 & 0.04 & 0.39 \\
\hline crude protein, $\mathrm{kg}$ & 272 & 292 & 273 & 6.75 & 0.40 \\
\hline $\mathrm{PDIN}^{1}, \mathrm{~g}$ & 222 & 233 & 216 & 5.05 & 0.39 \\
\hline $\mathrm{PDIE}^{1}, \mathrm{~g}$ & 224 & 228 & 208 & 5.02 & 0.24 \\
\hline $\mathrm{UFL}^{1}$ & 1.29 & 1.42 & 1.33 & 0.03 & 0.22 \\
\hline
\end{tabular}

${ }^{1}$ IZ-INRA (2001)

a,b different superscripts within a row indicate statistically significant differences $(\mathrm{P} \leq 0.05)$

Feeding linseed and fish oil had a significant $(\mathrm{P} \leq 0.05)$ effect on the fatty acid profile of meat fat (Table 4). Oleic acid $\mathrm{C}_{18: 1}$ was the most abundant acid in meat fat and its proportions in different groups were unrelated to the feeding applied. 
Table 4 . The fatty acid composition of meat, $g / 100 \mathrm{~g}$ total fatty acids

\begin{tabular}{|c|c|c|c|c|c|}
\hline \multirow{2}{*}{ Fatty acids } & \multicolumn{3}{|c|}{ Groups } & \multirow{2}{*}{ SEM } & \multirow{2}{*}{$\mathrm{P}$} \\
\hline & control & linseed & fish oil & & \\
\hline $\mathrm{C}_{16: 0}$ & $18.72^{\mathrm{a}}$ & $15.40^{\mathrm{b}}$ & $18.54^{\mathrm{a}}$ & 0.48 & $<0.01$ \\
\hline $\mathrm{C}_{18: 0}$ & $13.16^{\mathrm{a}}$ & $12.51^{\mathrm{a}}$ & $10.84^{b}$ & 0.27 & $<0.01$ \\
\hline $\mathrm{C}_{18: 1}$ & 27.93 & 26.08 & 27.97 & 0.79 & 0.55 \\
\hline$C_{18: 2} n-6$ & 19.64 & 22.03 & 18.07 & 0.86 & 0.17 \\
\hline$C_{18: 3} n-3$ & $0.58^{\mathrm{b}}$ & $3.33^{\mathrm{a}}$ & $0.78^{\mathrm{b}}$ & 0.26 & $<0.01$ \\
\hline CLA & 0.09 & 0.12 & 0.11 & 0.01 & 0.65 \\
\hline $\mathrm{C}_{20: 5} \mathrm{n}-3 \mathrm{EPA}$ & $0.38^{\mathrm{b}}$ & $0.80^{\mathrm{b}}$ & $2.85^{\mathrm{a}}$ & 0.28 & $<0.01$ \\
\hline $\mathrm{C}_{22: 6} \mathrm{n}-3$ DHA & $0.23^{\mathrm{b}}$ & $0.29^{\mathrm{b}}$ & $1.01^{\mathrm{a}}$ & 0.08 & $<0.01$ \\
\hline SFA & $34.94^{\mathrm{a}}$ & $30.06^{\mathrm{b}}$ & $32.07^{\mathrm{ab}}$ & 0.69 & 0.01 \\
\hline MUFA & 31.37 & 29.03 & 31.62 & 0.89 & 0.44 \\
\hline PUFA n-3 & $2.12^{\mathrm{b}}$ & $5.93^{\mathrm{a}}$ & $7.37^{\mathrm{a}}$ & 0.54 & $<0.01$ \\
\hline PUFA n-6 & 27.91 & 30.66 & 24.90 & 1.23 & 0.17 \\
\hline$n-6 / n-3$ & $13.20^{\mathrm{a}}$ & $5.32^{\mathrm{b}}$ & $4.11^{\mathrm{b}}$ & 0.84 & $<0.01$ \\
\hline
\end{tabular}

${ }^{a, b}$ different superscripts within a row indicate statistically significant differences $(\mathrm{P} \leq 0.05)$

Linseed reduced the level of palmitic acid, while fish oil reduced the stearic acid content of meat fat in relation to the control group $(\mathrm{P} \leq 0.05)$. In the experimental groups, the overall SFA content was found to decrease, although significant differences in relation to the control group were only found for linseed feeding. Calves fed linseed had a higher $(\mathrm{P} \leq 0.05)$ level of linolenic acid than in the other groups, while fish oil significantly increased the proportions of EPA and DHA in meat fat $(\mathrm{P} \leq 0.05)$. In both experimental groups, the total $n-3$ PUFA content of meat fat increased $(\mathrm{P} \leq 0.05)$ in relation to the control group. There was also a tendency towards an increased CLA level in the meat of calves receiving linseed and fish oil, although the differences were not significant. Both fish oil and linseed markedly reduced the n-6/n-3 PUFA ratio in meat fat.

The fat sources used had no significant effect $(\mathrm{P}>0.05)$ on the dry matter, crude protein and fat content or physicochemical traits of meat (Table 5). Differences were significant only for colour lightness measured $48 \mathrm{~h}$ post-mortem. Compared with the control group, linseed clearly brightened meat colour $(\mathrm{P} \leq 0.05)$. The group of linseed-fed calves showed a tendency towards lighter colour of meat $24 \mathrm{~h}$ post-mortem, smaller redness and greater yellowness compared with the other groups, at both 24 and $48 \mathrm{~h}$ post-mortem. In calves receiving the analysed dietary fat sources, there was a tendency towards poorer meat tenderness in relation to the control group. In all the groups, meat refrigerated for $48 \mathrm{~h}$ was characterized by lighter colour and greater yellowness compared with the meat refrigerated for $24 \mathrm{~h}$. During cold storage of meat, there was a slight decrease in $\mathrm{pH}$. 
Fish oil significantly reduced the sensory quality of meat (Table 5). In the group of calves receiving fish oil, the meat was characterized by the poorest structure, taste and aroma $(\mathrm{P} \leq 0.05)$

Table 5. Physicochemical and sensory traits of meat

\begin{tabular}{|c|c|c|c|c|c|}
\hline \multirow{2}{*}{ Item } & \multicolumn{3}{|c|}{ Groups } & \multirow{2}{*}{ SEM } & \multirow{2}{*}{$\mathrm{P}$} \\
\hline & control & linseed & fish oil & & \\
\hline Dry matter, \% & 22.0 & 21.9 & 21.6 & 0.14 & 0.41 \\
\hline Crude protein, $\%$ & 19.4 & 19.8 & 19.4 & 0.19 & 0.63 \\
\hline Crude fat, $\%$ & 1.04 & 1.15 & 1.19 & 0.06 & 0.55 \\
\hline Thermal weight loss, $\%$ & 32 & 26 & 29 & 1.19 & 0.14 \\
\hline Tenderness, $\mathrm{kg} / \mathrm{cm}^{2}$ & 13.3 & 14.9 & 15.4 & 1.00 & 0.68 \\
\hline $\mathrm{pH}_{45 \min }$ & 5.88 & 5.88 & 5.99 & 0.04 & 0.49 \\
\hline $\mathrm{pH}_{24 \mathrm{~h}}$ & 5.74 & 5.70 & 5.71 & 0.03 & 0.91 \\
\hline \multicolumn{6}{|l|}{ Meat colour ${ }_{24 \mathrm{~h}}$} \\
\hline lightness (L) & 47.42 & 50.05 & 47.11 & 0.57 & 0.06 \\
\hline redness (a) & 18.62 & 17.95 & 18.99 & 0.28 & 0.31 \\
\hline yellowness (b) & 1.84 & 2.61 & 2.07 & 0.31 & 0.59 \\
\hline \multicolumn{6}{|l|}{ Meat colour $_{48 h}$} \\
\hline lightness (L) & $49.06^{\mathrm{b}}$ & $52.58^{\mathrm{a}}$ & $50.65^{\mathrm{ab}}$ & 0.61 & 0.05 \\
\hline redness (a) & 18.54 & 17.22 & 18.43 & 0.34 & 0.21 \\
\hline yellowness (b) & 3.86 & 4.22 & 3.70 & 0.35 & 0.83 \\
\hline Texture & $3.67^{\mathrm{a}}$ & $3.26^{\mathrm{ab}}$ & $3.09^{\mathrm{b}}$ & 0.09 & 0.03 \\
\hline Aroma intensity & $3.72^{\mathrm{a}}$ & $3.51^{\mathrm{ab}}$ & $3.32^{\mathrm{b}}$ & 0.06 & 0.01 \\
\hline Aroma desirability & $4.01^{\mathrm{a}}$ & $3.72^{\mathrm{a}}$ & $3.31^{\mathrm{b}}$ & 0.08 & $<0.01$ \\
\hline Juiciness & 3.54 & 3.72 & 3.43 & 0.07 & 0.29 \\
\hline Taste intensity & 3.60 & 3.46 & 3.42 & 0.05 & 0.37 \\
\hline Taste desirability & $3.84^{\mathrm{a}}$ & $3.67^{\mathrm{ab}}$ & $3.40^{\mathrm{b}}$ & 0.07 & 0.03 \\
\hline
\end{tabular}

$\mathrm{a}, \mathrm{b}-\mathrm{P} \leq 0.05$

\section{DISCUSSION}

The health value of meat has long been a subject of controversy among nutritionists. On the one hand, meat is a basic constituent of the human diet as a source of highly valuable protein as well as iron, zinc and group B vitamins. On the other hand, meat has been held responsible for many diseases of modern civilization due to the high content and unfavourable composition of fat containing a dominant proportion of saturated fatty acids (Maloney, 2001). The modification of meat composition, aimed at increasing the proportion of PUFA (especially healthpromoting n-3 PUFA) while reducing the proportion of undesirable SFA, is con- 
sistent with modern nutritional recommendations (FAO/WHO, 1993). However, another matter is the consumer acceptance of this meat, because healthy food is not necessarily tasty and appetizing, and these are the traits considered by meat buyers.

Compared with the control group, calves receiving a linseed diet achieved significantly better daily weight gains and higher final body weight, unlike calves fed the fish oil diet. Because the intake of feed, nutrients and, above all, energy, was equal in all the groups, the better gains in calves fed linseed were probably due to the form of fat given to the animals. According to Scollan et al. (2001) it is possible that the biohydrogenation of linseed oil fed in ground form is lower than that of fish oil due to slower release of the oil from linseed cell structures. In this way, linseed fat may inhibit the growth and activity of rumen bacteria to a lesser extent and thus give better production results than fish oil. Wachira et al. (2000) reported that feeding fish oil depressed the intake and performance of lambs, an effect that was associated with a reduction in microbial growth and efficiency in the rumen.

The present study showed that linseed and fish oil supplementation of the calf diets had no effect on the basic nutrient content of meat, but caused clear changes in the fatty acid profile of intramuscular fat. The decrease in the SFA content of meat fat, observed particularly when linseed was fed, was probably due to the inhibition of de novo synthesis of SFA in ruminants under the influence of considerable amounts of SFA in the diets (Doreau and Chilliard, 1997). Linseed reduced the level of palmitic acid, as also shown by Scollan et al. (2001) for heifers. Fish oil significantly reduced the level of stearic acid in meat fat, which has been ascribed by some authors to the inhibiting effect of dietary fish oil on rumen microorganisms taking part in the last stage of biohydrogenation of vaccenic acid $\mathrm{C}_{18: 1}$ trans into stearic acid $\mathrm{C}_{18: 0}$ (Wachira et al., 2000).

The increased content of $\mathrm{C}_{18: 3} \mathrm{n}-3$ in the meat fat of calves fed the linseed diet, and of EPA and DHA in calves receiving fish oil diets, shows that part of these acids avoided biohydrogenation in the rumen and was built into intramuscular fat (Strzetelski et al., 2003; Cooper et al., 2004; Wistuba et al., 2006). Despite the lack of EPA and DHA in the control and linseed diets, increased levels of EPA and DHA (proportional to the level of $\mathrm{C}_{18: 3} \mathrm{n}-3$ ) were observed in calves receiving these diets. This supports the hypothesis that in ruminants these acids can develop from their precursor (linolenic acid), while increasing the availability of $\mathrm{C}_{18: 3} \mathrm{n}-3$ in the diet increases the synthesis of long-chain fatty acids (Dewhurst et al., 2003).

The minimal tendency towards increased CLA content in the linseed and fish oil groups was probably due to the higher content of linoleic acid in the total fat of linseed and fish oil concentrates (1.46 g and $1.11 \mathrm{~g}$, respectively) than in the control group $(0.78 \mathrm{~g})$.

From a dietary point of view, the decrease in the $n-6 / n-3$ PUFA ratio in meat fat, for both linseed and fish oil diets, is very significant. The values obtained are 
consistent with the recommendations of FAO/WHO experts (1993), according to whom the n-6/n-3 PUFA ratio should be close to $4-6$. The $n-6 / n-3$ PUFA value depends largely on the composition and proportions of fatty acids in the diets fed. The use of diets rich in n-3 PUFA in animal feeding increases the proportion of these acids in intramuscular fat while reducing the level of $n-6$ PUFA and the n-6/n-3 PUFA ratio (Raes et al., 2004).

In addition to nutritive value, consumers pay considerable attention to the sensory quality of meat. The first quality trait considered by meat buyers is the colour of meat. It reflects meat freshness and depends mainly on the content and chemical structure of the principal pigment, myoglobin (Geay et al., 2001). In the group of calves receiving linseed oil, meat colour was found to become lighter, which is hard to explain. As in the present experiment, Wistuba et al. (2006), who used a $3 \%$ fish oil supplement in heifer diets, noted no changes in meat colour. After $48 \mathrm{~h}$ of cold storage, a decrease in meat $\mathrm{pH}$, related to post-mortem acidification of meat due to glycogen metabolism, was observed. This phenomenon was closely associated with the change in colour observed $48 \mathrm{~h}$ later, because low $\mathrm{pH}$ contributes to lighter colour (Geay et al., 2001).

Being the most important sensory trait of meat, tenderness is a result of many live factors and post-mortem maturation of meat, and largely depends on carcass handling after slaughter (Sinclair et al., 1998). The observed slight decrease in meat tenderness in the experimental groups, especially when fish oil was fed, resulted perhaps from a slightly greater reduction in the $\mathrm{pH}$ of meat of calves from this group. The decrease in $\mathrm{pH}$ during post-mortem chilling has a negative effect on meat tenderness (Thompson, 2002).

Palatability is an organoleptic trait that includes mainly taste and aroma. Meat aroma is determined by volatile aromatic compounds, while taste is associated with water- and fat-soluble compounds that accumulate in meat during maturation and form during thermal treatment (Farmer et al., 1994). Intramuscular fat has a significant effect on taste. The structure, taste and aroma of meat deteriorated clearly after the use of fish oil in calf nutrition. Probably, some compounds responsible for the specific aroma of fish passed together with oil into muscle tissue. These findings are in agreement with the results of Wistuba et al. (2006), who reported that meat palatability deteriorated markedly after the use of fish oil in the feeding of heifers.

\section{CONCLUSIONS}

The results obtained show that linseed with a high linolenic acid content and fish oil containing considerable amounts of long-chain EPA and DHA fatty acids are excellent feeds that increase the level of essential n-3 PUFA in calf meat and 
thus improve its health-promoting value. The consumption of this meat can reduce the deficiency of essential n-3 fatty acids, especially in humans eating no fish. Linseed has no negative effect on the sensory quality of meat and can be used in meat production. However, fish oil clearly has an adverse effect on meat taste and aroma and probably will not be used in large-scale meat production. Sensory quality is the main factor determining the choice of food. If the aroma and taste of meat is unattractive, the consumer will refuse to buy it despite its health-promoting properties.

\section{REFERENCES}

AMSA, 1995. Research Guidelines for Cookery, Sensory Evaluation, and Instrumental Tenderness Measurements of Fresh Meat. Amer. Meat Sci. Assoc. Chicago, Il

AOAC, 1998. Association of Official Analytical Chemists, Official Methods of Analysis. 16th Edition. Gaithersburg, MD

Bauman D.E., Perfield II J.W., de Veth M.J., Lock A.L., 2003. New perspectives on lipid digestion and metabolism in ruminants. Proceedings of Cornell Nutrition Conference, pp. 175-189

Boccard R., Buchter L., Casteels E., Cosentino E., Dransfield E., Hood D.E., Joseph R.L., McDougall D.B., Rhodes D.N., Schön I., Timbergen B.J., Touraille C., 1981. Procedures for measuring meat quality characteristics in beef production experiments. Report of a Working Group in the Commission of the European Communities (CEC) Beef Production Research Programme. Livest. Prod. Sci. 8, 385-397

Borowiec F., Zając T., Kowalski Z.M., Micek P., Marciński M., 2001. Comparison of nutritive value of new commercial linseed oily cultivars for ruminants. J. Anim. Feed Sci. 10, 301-308

Cooper S.L., Sinclair L.A., Wilkinson R.G., Hallett K.G., Enser M., Wood J.D., 2004. Manipulation of the n-3 polyunsaturated fatty acid content of muscle and adipose tissue in lambs. J. Anim. Sci. 82, 1461-1470

Dewhurst R.J., Scollan N.D., Lee M.R.F., Ougham H.L., Humphreys M.O., 2003. Forage breeding and management to increase the beneficial fatty acid content of ruminant products. Proc. Nutr. Soc. 62, 329-336

Doreau M., Chilliard Y., 1997. Digestion and metabolism of dietary fat in farm animals. Brit. J. Nutr. 78, Suppl. 1, S15-S35

Enser M., Scollan N.D., Choi N.J., Kurt E., Hallett K., Wood J.D., 1999. Effect of dietary lipid content on the conjugated linoleic acid (CLA) in beef muscle. Anim. Sci. 69, 143-146

FAO/WHO, 1993. Report of Joint Expert Consultation. Fats and Oils in Human Nutrition. Rome, FAO Food and Nutrition, Paper No. 57

Farmer L.J., 1994. The role of nutrients in meat flavour formation. Proc. Nutr. Soc. 53, 327-333

Geay Y., Bauchart D., Hocquette J., Culioli J., 2001. Effect of nutritional factors on biochemical, structural and metabolic characteristics of muscles in ruminants, consequences on dietetic value and sensorial qualities of meat. Reprod. Nutr. Develop. 41, 1-26

Givens D.I., Cottrill B.R., Davies M., Lee P.A., Mansbridge R.J., Moss A.R., 2000. Sources of n-3 polyunsaturated fatty acids additional to fish oil for livestock diets - a review. Nutr. Abstr. Rev. B 70, 1-19

Kris-Etherton P.M., Taylor D.S., Yu-Poth S., Huth P., Moriarty K., Fishell V., Hargrove R.L., Zhao G., Etherton T.D., 2000. Polyunsaturated fatty acids in the food chain in the United States. Amer. J. Clin. Nutr. 71, Suppl., 179S 
Maloney A.P., Mooney M.T., Kerry J.P., Troy D.J., 2001. Producing tender and flavoursome beef with enhanced nutritional characteristics. Proc. Nutr. Soc. 60, 221-229

Raes K., De Smet S., Balcaen A., Claeys E., Demeyer D., 2003. Effect of diets rich in n-3 polyunsatured fatty acids on muscle lipids and fatty acids in Belgian Blue double-muscled young bulls. Reprod. Nutr. Develop. 43, 331-45

Raes K., De Smet S., Demeyer D., 2004. Effect of dietary fatty acids on incorporation of long chain polyunsaturated fatty acids and conjugated linoleic acid in lamb, beef and pork: a review. Anim. Feed Sci. Tech. 113, 199-221

SAS Enterprise Guide, 2002. Version 2.0, SAS Institute Inc. Cary, NC

Scollan N.G., Choi N.J., Kurt E., Fisher A.V., Enser M., Wood J.D., 2001. Manipulating the fatty acid composition of muscle and adipose tissue in beef cattle. Brit. J. Nutr. 85, 115-124

Shahidi F., Miraliakbari H., 2004. Omega-3 (n-3) fatty acids in health and disease: Part 1 Cardiovascular disease and cancer. J. Med. Food 7, 387-401

Sinclair K.D., Cuthbertson A., Rutter A., Franklin M.F., 1998. The effects of age at slaughter, genotype and finishing system on the organoleptic properties and texture of bull beef from suckled calves. Anim. Sci. 66, 329-340

Strzetelski J., Borowiec F., Niwińska B., Zymon M., 2003. Effect of two linseed oily cultivars and soluble dried maize on fatty acid composition of calf meat. Ann. Anim. Sci., Suppl. 2, 65-69

Thompson J.M., 2002. Managing meat tenderness. Meat Sci. 60, 365-369

Wachira A.M., Sinclair L.A., Wilkinson R.G., Hallett K., Enser M., Wood J.D., 2000. Rumen biohydrogenation of $n-3$ polyunsaturated fatty acids and their effects on microbial efficiency and nutrient digestibility in sheep. J. Agr. Sci. 135, 419-428

Wistuba T.J., Kegley E.B., Apple J.K., 2006. Influence of fish oil in finishing diet on growth performance, carcass characteristics, and sensory evaluation of cattle. J. Anim. Sci. 84, 902-909 